\title{
Status and conservation of parrots and parakeets in the Greater Antilles, Bahama Islands, and Cayman Islands
}

\author{
JAMES W. WILEY
}

\section{Summary}

In the 1490 a minimum of 28 species of psittacines occurred in the West Indies. Today, only $43 \%$ (12) of the species survive. All macaws and most parakeet species have been lost. Although the surviving parrot fauna of the Greater Antilles, Cayman Islands, and Bahama Islands has fared somewhat better than that of the Lesser Antilles, every species has undergone extensive reductions of populations and all but two have undergone extensive reductions in range, mostly as a result of habitat loss, but also from persecution as agricultural pests, conflicts with exotic species, harvesting for pets, and natural disasters. The Cayman Brac Parrot Amazona leucocephala hesterna, with its tiny population (less than 150 individuals in the wild) and range, and the Puerto Rican Parrot $A$. vittata, with about $22-23$ birds in the wild and 56 individuals in captivity, must be considered on the verge of extinction and in need of (in the latter's case, continuing) aggressive programmes of research and management. Other populations declining in numbers and range include the Yellow-billed Amazona collaria, and Black-billed A. agilis Parrots of Jamaica, Hispaniolan Parakeet Aratinga chloroptera, Hispaniolan Parrot Amazona ventralis, Cuban Parrot A. leucocephala leucocephala and, most seriously, Cuban Parakeet Aratinga euops. The population of the Grand Cayman Parrot (Amazona leucocephala caymanensis), although numbering only about 1,000 birds, appears stable and the current conservation programme gives hope for the survival of the race. An active conservation and public education programme has begun for the Bahama Parrot $A$. l. bahamensis, which still occurs in good numbers on Great Inagua Island, but is threatened on Abaco Island. Recommendations for conservation of parrots and parakeets in the region include (1) instituting long-term programmes of research to determine distribution, status, and ecology of each species; (2) developing conservation programmes through education and management approaches that are culturally, politically, and economically sensitive to the region; and (3) providing and protecting habitat within suitably sized reserves.

\section{Introduction}

Islands have particularly fragile ecosystems. They are often distant from sources of biological dispersion. Compared with mainlands, islands have limited area, with little diversity of fauna and habitat, and key habitats are prone to extensive "overnight" destruction by man. The West Indies are typical of this pattern of rapid habitat change and subsequent loss of fauna. The history of West Indian psittacines is indicative of the magnitude of change that has occurred in the biota of the region.

I review the problems facing parrots of the Greater Antilles, Bahama Islands, and Cayman Islands, the conservation needs for these island parrots, and the 
potential consequences if such measures are not undertaken. First, I present a summary of the region's historical and present parrot fauna, original ecosystem structure, and threats to the area's psittacines. Next, I report on the status of the individual species in the region, summarizing what is known of past and present distribution and habitat, population trends, current threats, and conservation measures under way. Finally, I make general recommendations to consider in developing conservation programmes for the region's parrots.

\section{Historical and present psittacine fauna of the Greater Antilles, Bahama Islands, and Cayman Islands}

At the time of Columbus's discovery of the West Indies, the psittacine fauna was rich, consisting of a minimum of 28 species (seven macaws, nine parakeets, and 12 amazon parrots: Figure 1 ). In less than 500 years, the parrot diversity of the region has been greatly reduced: all macaw species have disappeared, $63 \%$ of the native parakeet species have become extinct (Figure 2), and $25 \%$ of the species of amazon parrot have been lost (Figure 3). In total, only $43 \%$ of the original psittacine species survive today.

The Greater Antilles (Cuba, Hispaniola, Jamaica, Puerto Rico, Virgin Islands), Cayman Islands, and Bahama Islands were home to at least 13 species (four macaws, four parakeets, and five amazon parrots). Although the parrot fauna of these islands fared better than the Lesser Antillean parrots, $38 \%$ of the species in these northern islands have become extinct. Whereas all parakeets and parrots in the region continue to be at considerable risk of further decline through accelerating habitat loss, the four surviving species of parakeet seem to be especially vulnerable, judging from this group's history of extinction in the West Indies.

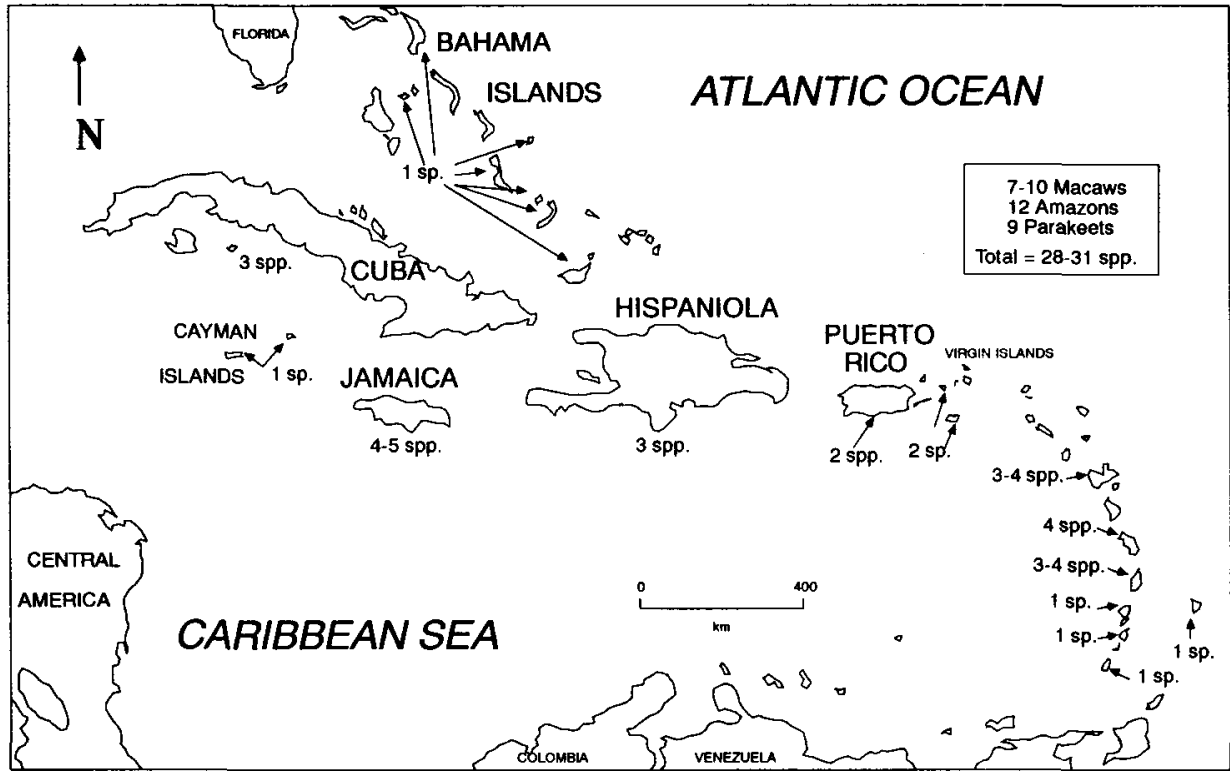

Figure 1. Distribution of West Indian macaws, parakeets, and amazon parrots, $1500 \mathrm{AD}$. 


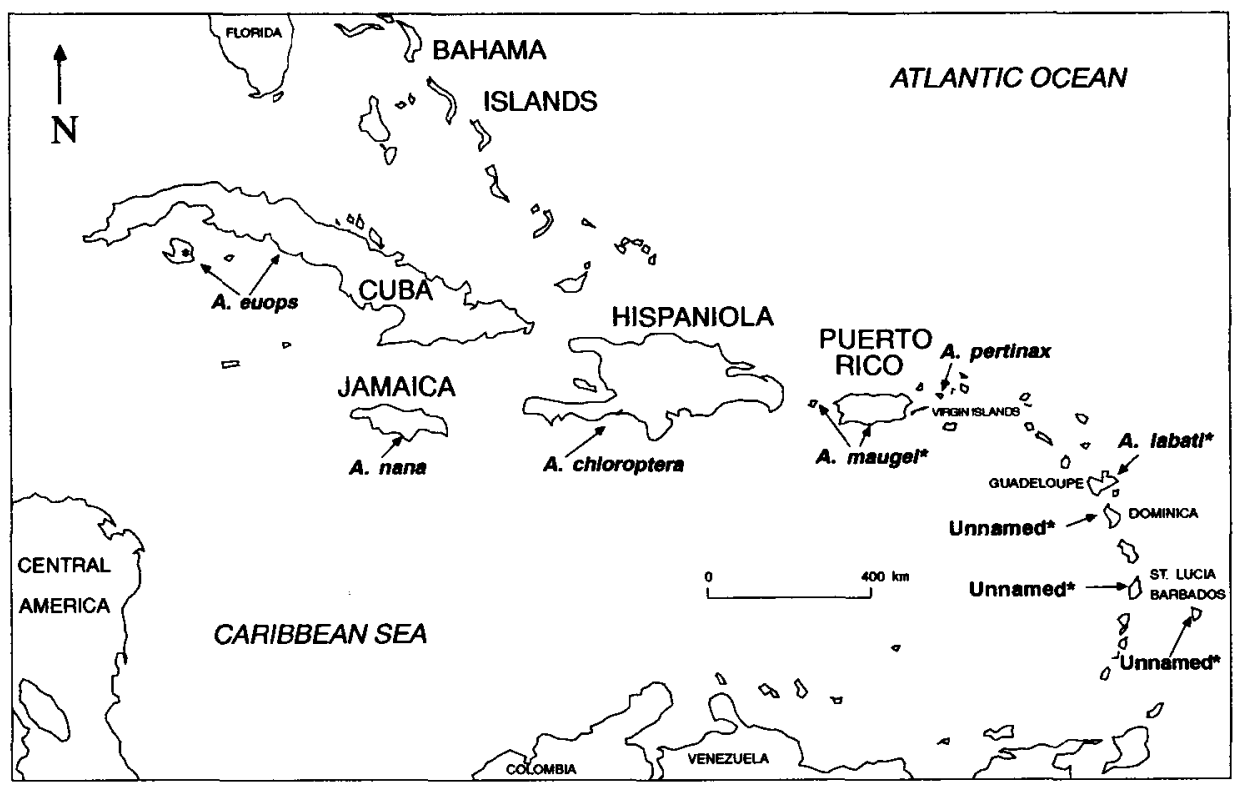

Figure 2. Distribution of extinct and extant species of Aratinga parakeets in the West Indies. ${ }^{*}$ Species extinct.

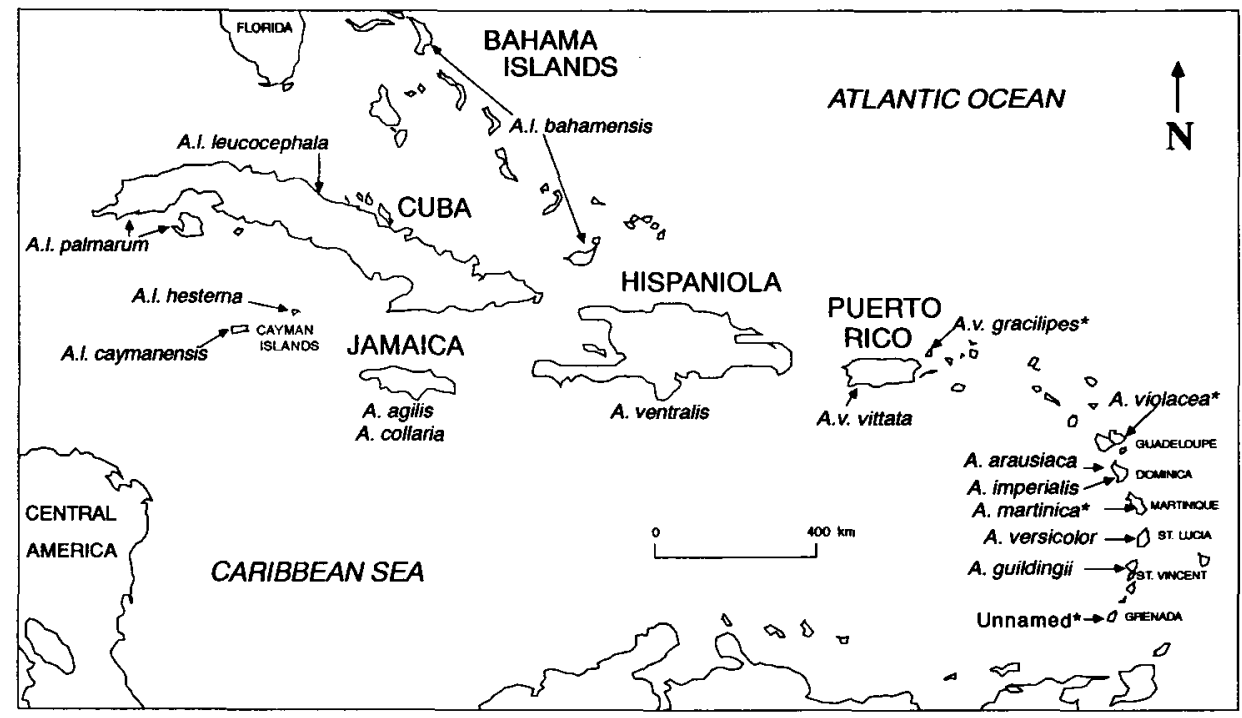

Figure 3. Distribution of extinct and extant species of Amazona parrots in the West Indies.

* Species extinct. 
Each of the major islands in the Greater Antilles has one native species of amazon parrot, except Jamaica which has two (Amazona agilis and $A$. collaria): $A$. ventralis on Hispaniola, $A$. vittata on Puerto Rico, and the $A$. leucocephala complex on Cuba (nominate leucocephala), Bahama Islands (race bahamensis), and the Cayman Islands (Grand Cayman with caymanensis, Cayman Brac with hesterna). Native Aratinga parakeets survive only on Cuba (Aratinga euops), Jamaica (A. nana), and Hispaniola (A. chloroptera).

During the past two decades, several exotic psittacine species have become established in the region, particularly in Puerto Rico and the U.S. Virgin Islands (Philibosian and Yntema 1977, Raffaele 1983). However, two species were established in the area considerably earlier. The Brown-throated Parakeet Aratinga pertinax is generally thought to have been introduced to St Thomas from Curaçao over a century ago (Philibosian and Yntema 1977, Forshaw 1978, Wiley in press a). The Green-rumped Parrotlet Forpus passerinus was introduced to Jamaica in 1918 (Bond 1956, Lack 1976), since when it has steadily increased its range and is now widespread in wooded cultivation from sea level to around $500 \mathrm{~m}$ elevation. The parrotlet is unusual among introduced species in the West Indies in that it occurs to some extent in natural forests.

\section{Original ecosystems}

Habitat diversity before Columbus's arrival in the West Indies ranged from simple to complex. Some islands that are small and low, like the Bahamas and Caymans, had relatively little vegetational diversity compared to the larger islands. Hispaniola, with an area of $81,000 \mathrm{~km}^{2}$ and two peaks higher than $3,000 \mathrm{~m}$, had several vegetational zones ranging from cactus scrub woodland in the arid coastal regions to alpine cloud-forest with extensive broadleaf forests. West Indian parrots originally occupied essentially all habitat types with foodbearing plants, including arid cactus-woodlands, wet and xeric broadleaf forests, palm savannas, pine woodlands, coppice, and mangrove forest. However, as land was cleared for cultivation, habitats were either destroyed or greatly altered, with moist forests of the coastal and lowland montane zones being the first to disappear. Today, only remote forests in the most rugged areas have escaped cutting, and only in these areas have parrots survived in numbers.

\section{Causes of declines in parrot populations}

Population declines and extinctions of parrots in the West Indies have resulted from many environmental problems, almost all of which were related to man's activities.

Habitat loss Undoubtedly, habitat degradation and loss resulting from agricultural and timber activities have been the most important factors in the decline of parrot populations. With few exceptions, West Indian psittacines require tree cavities for nesting. Cutting of mature forests left birds without nesting sites and, to a lesser extent, food and shelter. As mature forests disappeared, so did parrots. 
Persecution as agricultural pests As agriculture spread into psittacine habitat, farmers and birds came into conflict over crops. Both parrots and parakeets are still vigorously controlled to protect crops, but parakeets, particularly, are considered serious crop predators on all the islands.

Conflicts with exotics With European man came an array of alien species, some of which have been instrumental in the decline and extinction of parrots. Honeybees Apis mellifera and rats (especially Rattus rattus) compete with parrots for nest cavities (Wiley 1981, 1985, Snyder et al. 1987). Feral cats are predators of parrot eggs, chicks, and adults (Rodríguez-Vidal 1959, Snyder et al. 1987). More recently, introduced parrots have posed a threat to native populations through competition, hybridization, and disease (Snyder et al. 1987). In Puerto Rico, at least 11 psittacines, including five amazon parrots, are established (Raffaele 1983, pers. obs.), and threaten the native Puerto Rican Parrot.

Harvesting for pets Harvesting of chicks for pets has seriously affected most of the region's parrot species. Aside from the immediate impact of removing chicks from nests, harvesting can have long-lasting effects on parrot populations (Todd 1916). Some parrot nest cavities are destroyed in the process, thereby reducing available nesting habitat (Wiley 1981, 1985, Snyder et al. 1987). West Indian countries have made substantial improvements in regulating the harvest of young parrots, but the pet trade continues to take a heavy toll on some populations. Although not considered as valuable as amazon parrots, parakeets have been under local harvesting pressure for the pet trade on some islands, e.g. Isla de la Juventud (Isle of Pines) (Todd 1916), Dominican Republic (pers. obs.).

Natural disasters Hurricanes are a constant threat to island populations of parrots. When populations were widespread and consisted of many individuals, these tropical storms had little long-term effect on species. However, once populations became restricted in range through habitat loss and were reduced to many fewer individuals, hurricanes figured importantly in the extirpation and extinction of species (Wiley in press b). Disease has also become a more serious threat to the survival of native parrots because of recent introductions of exotic parrot species to the region.

\section{Present status of species: Cuba}

Like the other islands of the West Indies, Cuba has undergone extensive conversion of natural forests to cultivation and pastures. In 1812, 90\% of Cuba was covered with natural forests (Instituto Cubano de Geodesia y Cartografia 1978). Less than 100 years later, $54 \%$ was still in natural forests. Habitat destruction has since been even more extensive, and only small remnants of the original forests now survive (Figure 4). By 1975, just $18 \%$ of the island was covered by forests (Instituto Cubano de Geodesia y Cartografia 1978). However, the Cuban government has set aside as national parks and natural reserves several areas important to wildlife conservation. Nine national parks, including Península de Guanahacabibes National Park, Ciénaga de Zapata National Park, Ciénaga de Lanier National Park, and La Plata (Sierra Maestra) National Park, have been 


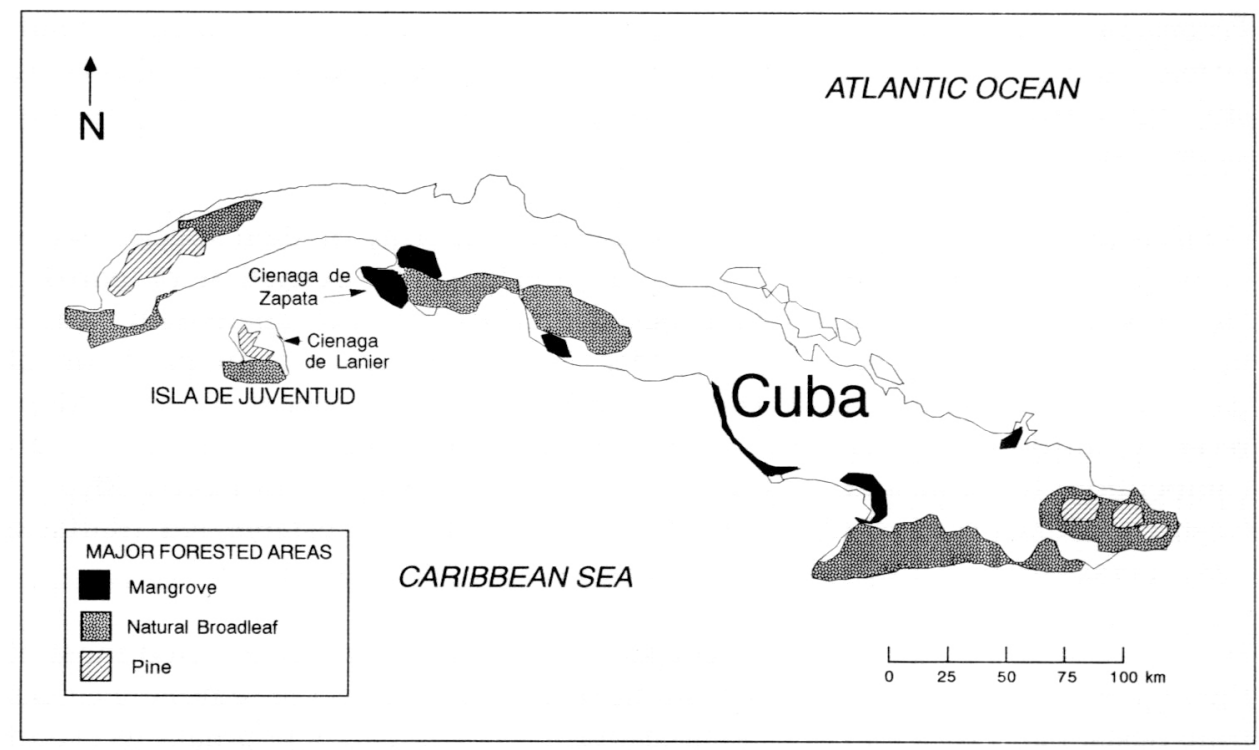

Figure 4. Major surviving forested areas and forest types in Cuba and the Isla de la Juventud (Isle of Pines) (source: Instituto Cubano de Geodesia y Cartografia 1978).

established on the main island and Isla de la Juventud. Additional areas have been preserved as wildlife refuges, incorporating more of the Ciénaga de Zapata and Isla de la Juventud.

\section{Cuban Parrot Amazona leucocephala leucocephala}

Distribution and habitat The Cuban Parrot was formerly widespread and common throughout Cuba and Isla de la Juventud (Garrido and García Montaña 1975). Two races are recognized by some: Amazona l. leucocephala of eastern Cuba, and A. l. palmarum of western Cuba and the Isla de la Juventud (Snyder $e t$ al. 1987; see Barbour 1943, Garrido and García Montaña 1975, García Montaña 1987 for alternative treatment). The species is locally found in all of the provinces, but is common only in the Ciénaga de Zapata, on the Península de Guanahacabibes, in the Sierra de Najasa (Camagüey), and in some mountainous zones (Sierra Maestra) in Granma and Santiago de Cuba provinces (Garrido and García Montaña 1975, García Montaña 1987, O. H. Garrido pers. comm. 1991, pers. obs.; Figure 5).

The parrot was once abundant throughout Isla de la Juventud, but the population underwent considerable declines, notably in the 1960s (García Montaña 1987). Currently, the largest population survives in the area of San Francisco de la Vega in the Ciénaga de Lanier (García Montaña 1987, O. H. Garrido pers. comm. 1991). The Cuban Parrot prefers dense forests and remote woodlands in both mountains and lowlands.

Status The parrot is generally considered to be locally common in the few remaining remote areas of Cuba, but elsewhere is rare or extirpated (Bond 1956, 


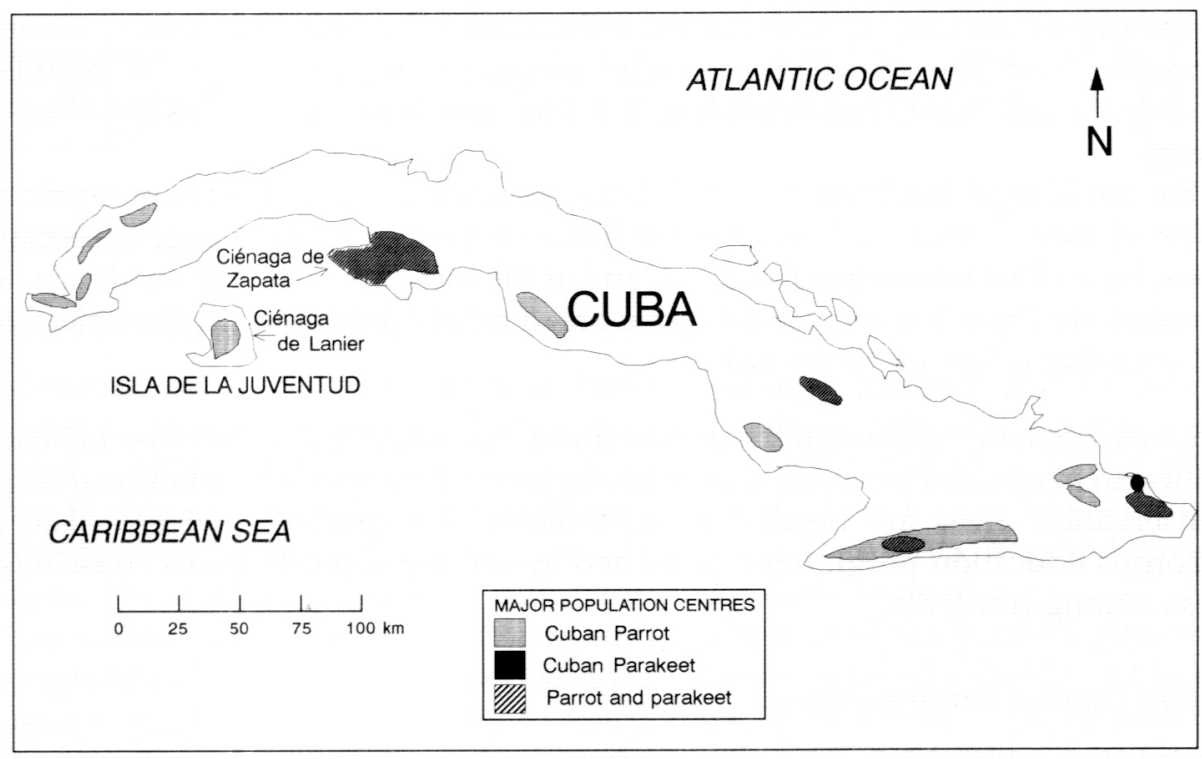

Figure 5. Major population centres of the Cuban Parrot Amazona leucocephala leucocephala and Cuban Parakeet Aratinga euops.

Garrido and García Montaña 1975, King 1978-1979, pers. obs.). Híram González (pers. comm. 1988) estimated a total population of 5,000 Cuban Parrots.

Population trend Declining. Barbour (1943) noted that the number of parrots was declining annually, and stated that within "a few years, parrots will be excessively rare in Cuba and its dependencies". The parrot continued to decline in range and numbers throughout Cuba until the late 1970s, when government measures were taken to control the exportation of parrots for pets. That control resulted in notable increases in several parrot populations in the $1980 \mathrm{os}(\mathrm{O} . \mathrm{H}$. Garrido pers. comm. 1991). The Isla de la Juventud population is considered to be recuperating from its 1960s low point (García Montaña 1987, O. H. Garrido pers. comm. 1991).

Threats García Montaña (1987) reported parrots much in demand as pets by Cubans and foreigners. Although the Cuban Parrot is protected from capture and shooting by national and international law, it is still marketed in East European countries. In 1988, U.S. Fish and Wildlife Service agents seized 49 Cuban Parrots en route to the United States. A lively trade in parrots as local pets also continues. Nevertheless, the most serious threat to the species is deforestation.

Conservation efforts The Amazona leucocephala complex of races is listed in Appendix I of the 1973 Convention on International Trade in Endangered Species of Wild Fauna and Flora (CITES), although Cuba is not a signatory of the treaty.

De las Pozas and González (1984) and Berovides Alvarez (1986) studied the 
behaviour of the Cuban Parrot in the wild during the breeding season. Hiram González and his associates continue intensive research on wild parrots. Rodríguez and Acosta (1986) studied A. l. leucocephala in captivity, as did Noegel (1977).

Ramon Noegel has bred both $A$. l. leucocephala and $A$. l. palmarum in captivity (Noegel 1981). Amazona l. leucocephala has also been bred in two East German zoos, by an East German aviculturist, and at the Moscow Zoo. The Academia de Ciencias de Cuba has an active captive-breeding programme with the objective of returning offspring to the wild.

Recommendations Although the important Ciénaga de Zapata and other habitats critical to parrot and parakeet survival have been made reserves, additional large conservation areas are needed in sites where the species survives. Also, a vigorous education programme is needed to develop a protectionist consciousness among residents.

\section{Cuban Parakeet Aratinga euops}

Distribution and habitat The parakeet was once abundant and widespread in Cuba and Isla de la Juventud (Barbour 1943). In the nineteenth century, Gundlach (1893) reported the species from the Ciénaga de Zapata, Trinidad Mountains, hills of Bayamo, and mountains of Guantánamo. It disappeared from Isla de la Juventud soon after the beginning of the twentieth century (Bangs and Zappey 1905). In 1915, it was believed the parakeet population in the Ciénaga de Zapata was the only one west of Camagüey (Barbour 1943). It was then still common in the forests of the Guantánamo Basin and in the mountains near Trinidad and south of Cumanayagua (Barbour 1943). Davis (1941) noted parakeet populations around Cienfuegos, Trinidad Mountains, and the southern Sancti Spiritus province (Guasimal). Currently, the parakeet is found throughout Cuba, except for La Habana Province (Garrido and García Montaña 1975, García Montaña 1980; Figure 5).

Barbour (1943) stated the parakeet requires virgin forests. It inhabits the wilder, heavily forested mountains, although it also occurs in palm savannas (Bond 1956).

Status Rare (Garrido and García Montaña 1975).

Population trend The Cuban Parakeet has not persisted as well as the parrot and has undergone an alarming decline in numbers.

Threats The Cuban Parakeet has been a popular cage bird, which has contributed to its decline (Todd 1916, Barbour 1943, García Montaña 1980). Gundlach (1893) had predicted that, at its rate of harvest for cage birds, the formerly abundant parakeet would soon disappear from the Isla de la Juventud. Apparently, that prediction was soon fulfilled (Bangs and Zappey 1905). Nevertheless, the main cause of its decline has been large-scale destruction of forests (Barbour 1943). 
Conservation efforts The parakeet is protected by law and receives additional protection within the Ciénaga de Zapata National Park and Refuge, and other reserve sites.

\section{Bahama Islands}

Bahama Parrot Amazona leucocephala bahamensis

Distribution and habitat The Bahama Parrot was once plentiful and probably present on all major islands of the Bahama Archipelago, although records exist for only Abaco, New Providence, San Salvador, Long, Crooked, Acklin's, and Great Inagua islands, and Long Cay (King 1978-1979, Buden 1979, Snyder et al. 1982; Figure 6). By the 1940s, it was found solely on Abaco, Acklin's, and Great Inagua. The Acklin's population was extirpated shortly thereafter.

The southern third of Abaco $\left(1,681 \mathrm{~km}^{2}\right)$ is considered the parrot's primary stronghold on that island (Snyder et al. 1982). Parrots occur islandwide on Great Inagua $\left(1,544 \mathrm{~km}^{2}\right)$, but are patchy in distribution. They formerly visited nearby Little Inagua and may continue to do so today (Snyder et al. 1982).

The parrot uses native broadleaf woodland and pine woodlands (King 19781979). The Abaco population nests in limestone solution holes in the ground, rather than traditional tree cavities as used by the Inagua population.

Status Although Buden (1979) considered the parrot common on Great Inagua, King (1978-1979) described it as rare throughout its range. Attrill (1981) thought

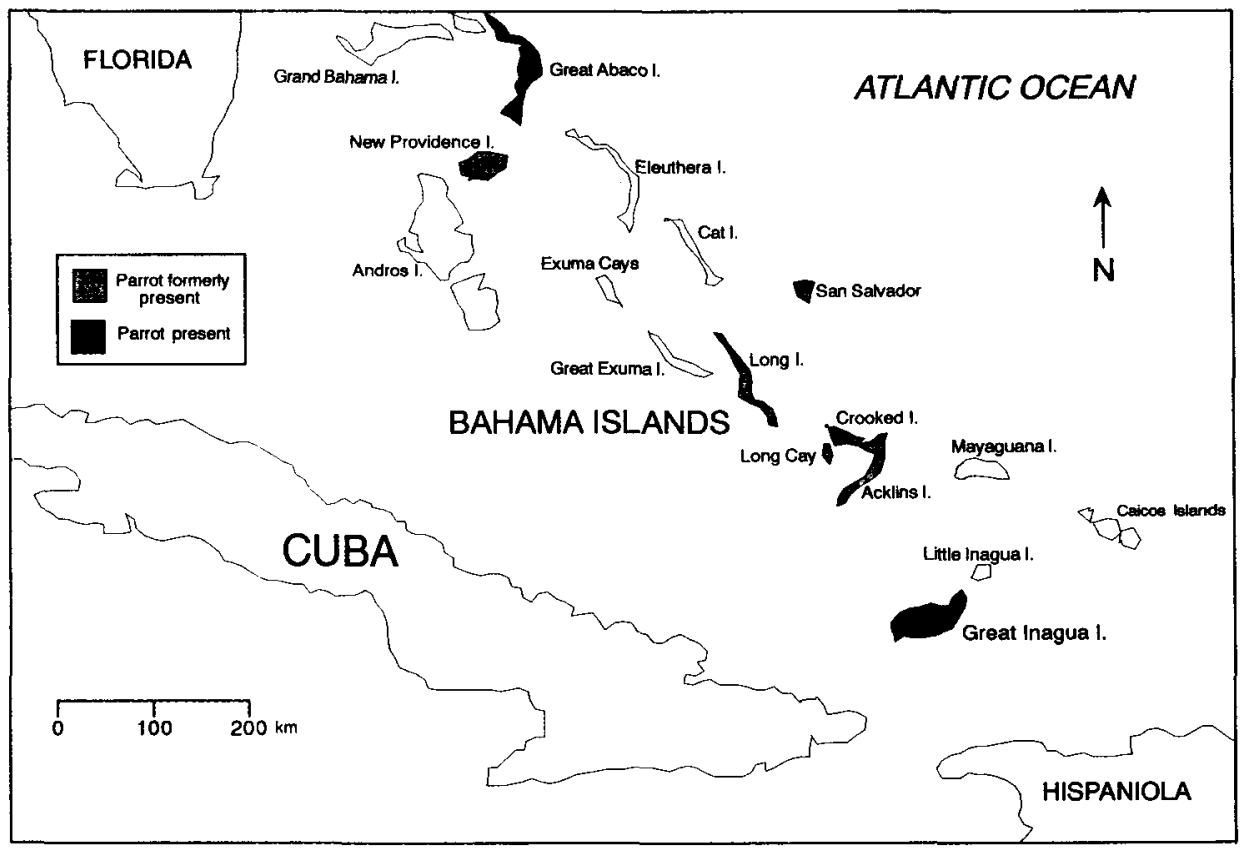

Figure 6. Bahama Islands, showing historical and present distribution of the Bahama Parrot Amazona leucocephala bahamensis. 
the total population (Abaco and Inagua) to be several hundred to 1,000+. Buden (1979) stated that the Inagua and Abaco populations each consisted of around 400-1,000 individuals. King (1978-1979) reported the population on Inagua to number $400-500$ birds. Snyder et al. (1982) estimated 450-800 individuals for Abaco. Most recently, Gnam and Burchsted (1991) estimated the Abaco population in January 1989 at $830-1,082$ birds.

Population trend The extant Bahama populations of Amazona l. bahamensis are thought to be stable (King 1978-1979, Snyder et al. 1982) but vulnerable to exotic predators, poaching, possible habitat loss and hurricanes. With its small population size, restricted distribution and several threats, the Bahama Parrot cannot be considered secure.

Threats A reduction in farming on Inagua has taken the pressure off that island's parrots, which were formerly considered crop pests. The human population has declined from 5,000 around 1900 to some 1,200 in the 1970 s (Attrill 1981). Roads are few so access into most areas used by parrots is poor.

Abaco is sparsely and unevenly populated. Aside from harvesting of pine Pinus caribaea, the economy is based on fishing, agriculture, and tourism. Threats to the Abaco parrot population include:

1. Habitat alteration. Destruction of pines and associated road construction in the 1950 a and 1960s were major intrusions into the primary habitat of Abaco parrots. Current pine management calls for cutting regenerating pines on an approximately 20-year rotation, which is certain to affect some parrot habitat.

2. Hunting. Most of the island was inaccessible until the 1950-1960s, but new road systems constructed for the lumber industry have allowed hunters to penetrate the parrot's habitat. Although shooting of parrots has perhaps declined as awareness of Bahamian laws protecting parrots has increased, fires that continue to be set by pig hunters have had a negative effect on parrot habitat.

3. Pet trade. Young of the now extirpated population on Acklin's Island were "regularly" transported to Nassau for sale (Allen 1905). The Abaco population was subjected to little harvesting of chicks until recently. A vigorous campaign has been launched by Rosemarie Gnam and the Bahamas National Trust to deter the parrot trade on Abaco.

4. Feral mammals. The small Indian mongoose Herpestes auropunctatus has not been introduced into the Bahamas, but feral cats are abundant on Abaco, where they are important predators of the vulnerable ground-nesting parrots (Gnam and Burchsted 1991, Gnam and Rockwell in press).

5. Hurricanes. Hurricane Betsy (1965) had a massive negative effect on parrot habitat in southern Abaco.

Conservation efforts The Bahamian government's Wild Birds Protection Act (1965, amended 1977) protects all wild birds, including parrots. In 1952, the government set a $\$ 500$ fine for molesting parrots. That fine is now widely respected and wild parrot numbers have perhaps increased since the 1960s. The Bahama Parrot has been recognized as at risk by the ICBP and IUCN (Interna- 
tional Union for Conservation of Nature) since 1966 (Vincent 1966-1971) and the U.S. Department of the Interior since 1970 (U.S. Bureau of Sport Fisheries and Wildlife 1970). The parrot is listed in Appendix I of CITES. The Bahamian government ratified CITES in 1979.

The largest of the Bahamas National Trust parks is on Inagua, and includes part of the parrot's range on this island (Attrill 1981). A 6,880 ha parrot reserve has been proposed by the Bahamas National Trust and by the Department of Lands and Surveys (Forestry Section) to be incorporated into a 27,519 ha (16.4\% of the island) forest reserve for southern Abaco Island. The Trust initiated a captive-breeding programme in 1977 and also sponsored educational programmes to increase concern for the parrot. Gnam (1988, 1990; also Gnam and Burchsted 1991) conducted a comprehensive study of the Bahama Parrot's biology on Abaco Island from 1985 to 1990 . That research has produced sound recommendations for the conservation of the species (Gnam 1990). In late 1990, RARE Center for Tropical Bird Conservation began an education programme in the Bahama Islands modelled on its successful efforts for parrots in St Lucia, Dominica, and St Vincent.

Recommendations An initial effort to develop effective population survey methods and determine current population size and distribution is needed on Great Inagua. Thereafter, periodic (alternate years) monitoring of the parrot population should be performed. A comprehensive long-range management plan based on sound knowledge of parrot biology is needed for Abaco Island. An immediate control programme for removal of feral cats from the nesting areas of the Abaco population is critical to the population's survival (Gnam 1990, Gnam and Burchsted 1991).

Also, it seems timely and prudent to re-establish $A$. $l$. bahamensis on other islands (Snyder et al. 1982, Gnam 1990). A reintroduction on Acklin's Island or northern Abaco Island now appears particularly feasible in view of the parrot's recent extirpation, stability of habitat in these areas, and the present respect by Bahamians of bird protection laws. The great strength of reintroduction is its power to rally public support for conservation. With this in mind, a reintroduction programme could be attempted as part of the forthcoming celebration of the 5 ooth anniversary of Columbus's discovery of the New World (in which, incidentally, his first gift from the native Bahamian Indians was a parrot; Morison 1963).

\section{Cayman Islands}

The two races of Amazona leucocephala inhabiting the Caymans have recently been of extreme concern because Hurricane Gilbert, one of the strongest tropical storms of this century, savaged these islands in September 1988 (Lehman 1989). Some parts of the islands suffered severe damage (pers. obs.). Many nesting trees were destroyed and vegetation was essentially stripped of leaves and fruit. Patricia Bradley (pers. comm. 1988) reported royal palm groves and tall mangrove forests on Grand Cayman levelled by the hurricane. The important mangrove habitat on Little Cayman was decimated. Nevertheless, the effects on the parrot populations appear to have been minimal, because 1991 numbers of 
birds on Grand Cayman and Cayman Brac were no less than before the storm (pers. obs.).

I shall first present information that pertains to both races, followed by details for each subspecies.

Habitat The Caymans are low coastal platform islands, with predominantly mangrove swamp woodland and dry evergreen woodland. The islands are small, Grand Cayman being $197 \mathrm{~km}^{2}$, Cayman Brac $38 \mathrm{~km}^{2}$, and Little Cayman $28 \mathrm{~km}^{2}$. Both races of Amazona leucocephala inhabit coastal and inland forests.

Threats Bradley (1986) reported several threats that were detrimental to parrot reproductive success in the Cayman Islands, including: (1) predation (by rats, Barn Owls Tyto alba, Smooth-billed Ani Crotophaga ani, Greater Antillean Grackle Quiscalus niger, feral cats), (2) disease (young dead in nest and infertile eggs), (3) starvation of young after a hurricane or period of drought, (4) flooded cavities, (5) felling of parrot nest trees by man, and (6) human harvest of chicks (11 nests in 1985). In addition, the species was locally listed as game until 1990. Parrots continue to be destroyed as crop pests, and wounded adult parrots that survive shooting are taken for captivity. However, perhaps the most serious threat to the parrot populations is the accelerated land development associated with tourism.

Conservation efforts Some bird sanctuaries have been established, but inclusion of larger tracts of habitat are essential to the populations' survival. The parrot was removed from the Cayman Islands game list in January 1990. Both races are listed in Appendix I of CITES. The Cayman Islands government has not ratified CITES, but the United Kingdom, with whom the islands are still politically allied, is a signatory of the treaty. The Cayman Brac and Grand Cayman parrots have been bred in captivity (Noegel 1974, 1976, 1981). In 1985, Bradley (1986) conducted an intensive field study of both races, which included determining their status, distribution, and reproductive biology. In late 1990, the National Trust for the Cayman Islands, in cooperation with RARE Center for Tropical Bird Conservation, began an extensive conservation programme for the Cayman Brac and Grand Cayman parrots.

Recommendations Large, effective parrot reserves must be established on each island. The extent and effect of crop depredations by parrots must be determined and means for managing this problem must be developed.

Grand Cayman Parrot Amazona leucocephala caymanensis

Distribution and habitat Amazona l. caymanensis ranges throughout Grand Cayman, except for central George Town, the eastern fringe of North Sound, the interior of the Central Mangrove Swamp, Booby Cay in North Sound, and the reclaimed land from Rum Point to Water Point (Bradley 1986; Figure 7).

Status Within its limited range, $A$. l. caymanensis has generally been described as common (Bond 1956, Johnston 1975, Olson et al. 1981, Bradley 1986). Noegel 


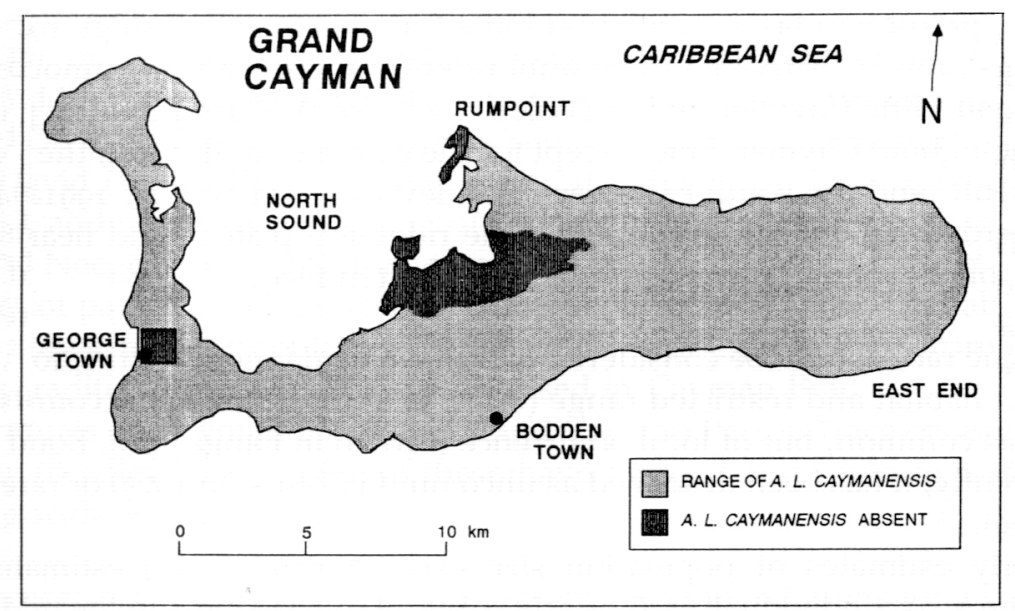

Figure 7. Grand Cayman, showing distribution of the Grand Cayman Parrot Amazona leucocephala caymanensis (after Bradley 1986).

(1981) estimated $35^{\circ}$ birds in the 1970s, but only about 200 birds by 1983 (in Bradley 1986). Bradley (1986) estimated the adult population in 1985 on Grand Cayman to be 935 (range $=674^{-1,239}$ ) individuals. That estimate seems to be accepted as reasonable by current local biologists (pers. obs.). Bradley found a "reasonable" fledging rate of 1.8 /nest (where no human disturbance occurred). She estimated the total number of juveniles in 1985 after fledging at 416 (range = $280-475$ ). The 1985 captive population of parrots on Grand Cayman was around 500 birds (Bradley 1986).

Population trend Recently declining, but possibly now stabilizing. At the turn of the century, Nicoll (1904) stated the Grand Cayman race was in no danger of extinction. However, Bradley (1986) reported that the population has been gradually declining over the past 20 years. Although she felt the present food supply and amount of habitat should ensure that the race will be in no danger of extinction for several years, the population should not be considered secure in view of the projected habitat loss, continued shooting for crop protection, harvest for the pet trade, and hurricanes, an ever-present threat.

Threats Moore (1985) reported extensive habitat destruction by man in Grand Cayman in the early 1980s. Further forest clearing can be expected with the growing tourist industry. Bradley (1985) mentioned that Hurricane David (1980) was responsible for the loss of many cavity-bearing trees.

Cayman Brac Parrot Amazona leucocephala hesterna

Distribution and habitat This subspecies occupies the smallest range of any amazon in the Caribbean. It once occurred on both Cayman Brac and Little Cayman. Cayman Brac birds were said to fly to Little Cayman $(7 \mathrm{~km})$ to feed, although the smaller island probably had its own breeding population (Bradley 
1986). The parrot was last recorded on Little Cayman in 1911 (Bangs 1916), but the species probably survived there until recently and even now rumours of its existence on Little Cayman persist (Wiley et al. 1991a). Currently, the parrot is found throughout Cayman Brac, except for the extreme south-west, the extreme eastern Bluff, and the south-east coast (Bradley 1986, Wiley et al. 1991a; Figure 8). The birds frequent the dry forest of the ridge-top plateau and nearby agricultural holdings along the coast, where they often feed.

Status The race should be considered in immediate danger of extinction, given its limited habitat and restricted range (Wiley et al. 1991a). Early accounts listed the race as common, but of local occurrence (Brown in Bangs 1916, Bond 1956). More recently, it has been described as uncommon (Johnston 1975) or rare (King 1978-1979).

No early estimates of population size exist. Noegel (1974) estimated the population at 150 individuals in the early 1970 , about 130 birds in the mid-1970s (Noegel 1977, 1981), and only 45 by the early 1980s (in Bradley 1986). In 1985, Bradley (1986) estimated a population consisting of about 26 adults (including 12 breeding pairs) and 11-15 juveniles. Bradley (1986) calculated a fledging rate of 1.25 birds per nest. In addition, she estimated more than 200 parrots in captivity (four times as many as in the wild population), although Noegel (1976) had located only eight captive hesterna on Cayman Brac a decade earlier.

In February 1991, the National Trust for the Cayman Islands conducted an extensive survey of the Cayman Brac Parrot population, which led to an estimate of 93-134 parrots for that island (Wiley et al. 1991a). This increase in numbers over Bradley's earlier counts probably represents a more intensive survey effort rather than a substantial increase in parrots.

Population trend Declining. Development plans and expanding agriculture for Cayman Brac make it likely that further declines will occur.

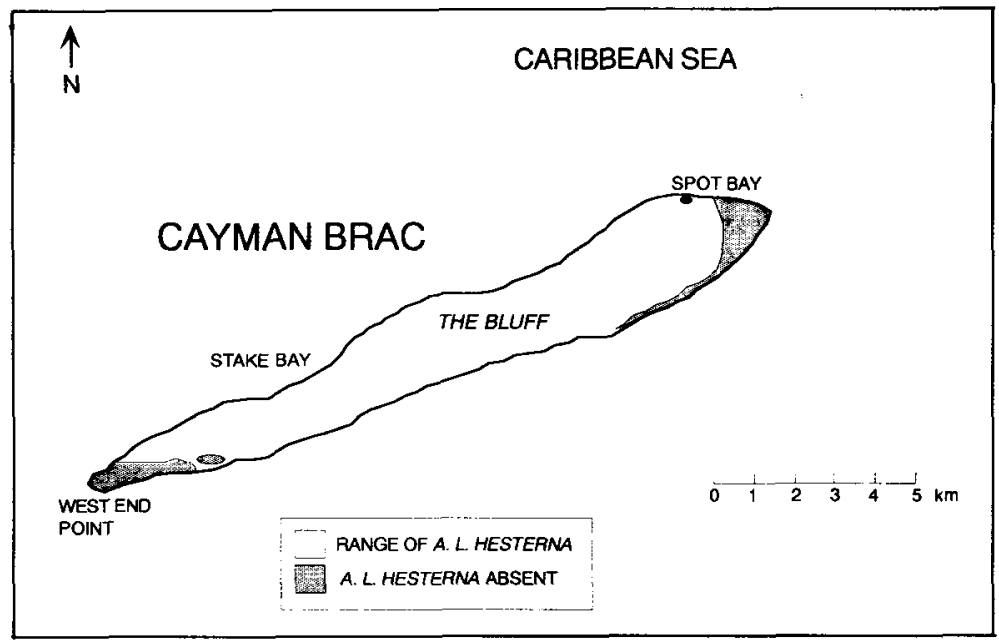

Figure 8. Cayman Brac, showing distribution of the Cayman Brac Parrot Amazona leucocephala hesterna (after Bradley 1986, Wiley et al. 1991a). 
Threats The restricted range of this race makes it particularly vulnerable to extinction by a violent storm. The subspecies was believed to have been extirpated from Little Cayman following a 1932 hurricane. Furthermore, Bradley felt the Cayman Brac population was seriously reduced in numbers by Hurricane David (1980). The new petrochemical industry on Little Cayman could result in additional development on Cayman Brac. With the emerging oil industry, Noegel (1981) reported increased visits to Cayman Brac and a greater demand for parrots. Feral cats are common in parrot habitat and probably pose a serious threat to the population (Wiley et al. 1991a). Shooting to protect fruit crops is traditional and extensively practised in Cayman Brac.

Individuals on Cayman Brac have Grand Cayman Parrots (race caymanensis) in captivity (Bradley 1986). Some of these have escaped and could hybridize and compete with the native race.

Recommendations Wiley et al. (1991a) present recommendations for a conservation programme to save the Cayman Brac Parrot. This programme includes research to determine nest-site requirements, nest-site availability, and breeding ecology. As with the Grand Cayman Parrot, the feeding ecology of the Cayman Brac race needs to be determined, with emphasis on the role of fruit crops in the parrot's diet. A management strategy must be developed to minimize farmerparrot interactions. Feral cats should be removed from parrot habitat. Monitoring of the population at regular intervals should be continued.

A carefully managed captive propagation programme seems appropriate in view of the small population size and restricted range of the Cayman Brac Parrot. Individuals for the captive flock should not be taken from the wild, but from extant captives. Reintroductions will be vital in bolstering numbers, and in increasing genetic diversity and geographic distribution. If habitat and parrot protection can be achieved, efforts to re-establish a population on Little Cayman should be attempted. Little Cayman may be too small, particularly with further development, to sustain a viable population of parrots, and introductions may have to be regularly made.

\section{Jamaica}

Jamaica has three surviving species of native psittacines. I present first information pertinent to all three species, then specifics for each.

Approximately $24 \%$ of Jamaica is still covered with forests (Cruz and Gruber 1981, Downer and Sutton 1990; Figure 9). However, natural forests are rapidly being replaced with plantations of pine and other fast-growing species, so that about $7 \%$ of the island's natural forest is moderately intact and only small parts of these areas are virgin (Asprey and Robbins 1953, Symes 1971, Cruz and Gruber 1981). Much of the important parrot habitat in the Hellshire Hills and Portland Ridge (dry limestone forest) has been spared from destruction by its aridity (Cruz and Fairbairn 1980). Similarly, other important parrot habitat has been uncut because of the inaccessibility of the terrain; e.g. much of the "Cockpit Country" and montane forest. Nevertheless, even these areas are being eroded by squatters encroaching on forest cores. Also, mining threatens the southern Cockpit Country, where extensive tracts have been leased for exploratory bauxite mining. 


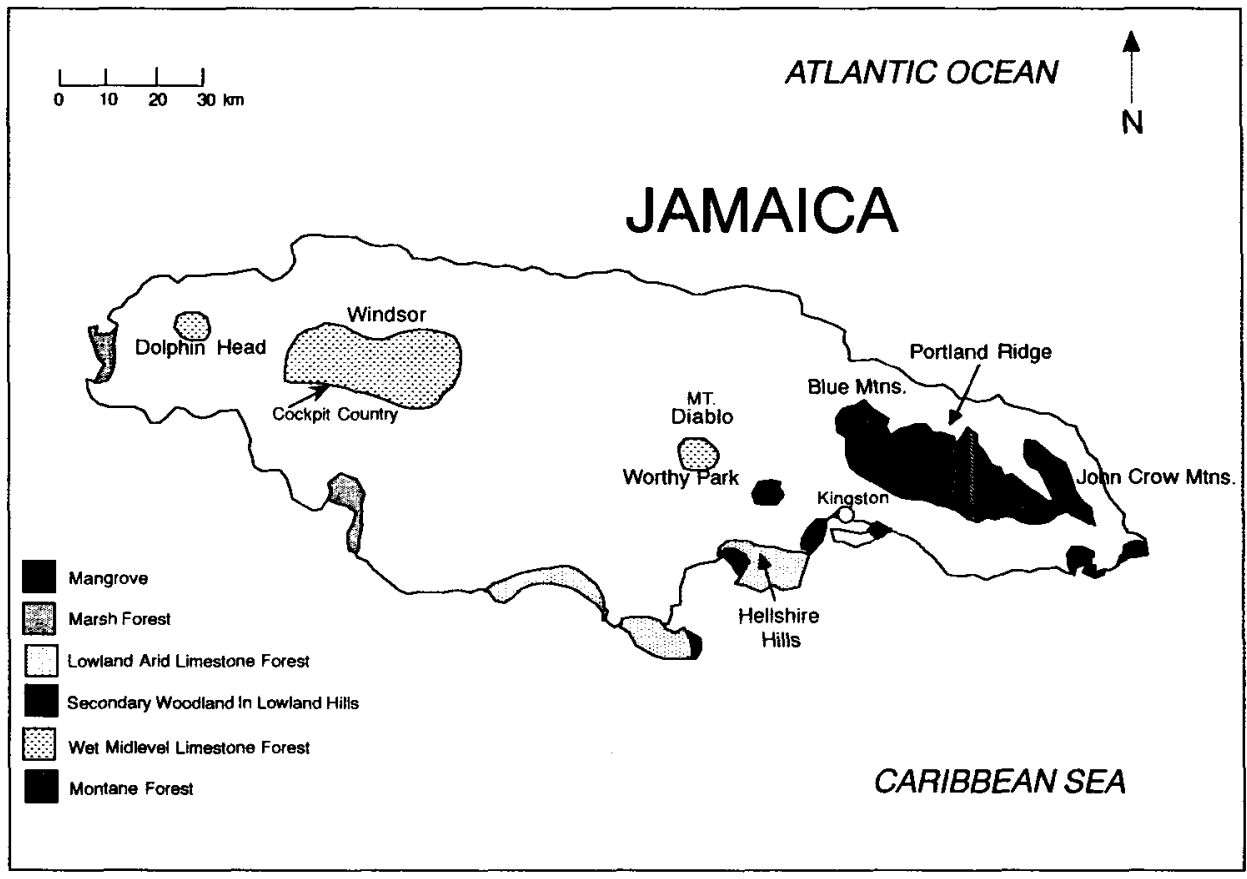

Figure 9. Major forested areas and forest types in Jamaica.

Conservation efforts important to the island's parrots include protection of habitat, control of harvesting for the pet trade, and control of shooting (Downer and Sutton 1990). The Forestry Acts of 1937 and 1973 provide certain forms of protection to some habitat, such as the Cockpit Country Forestry Reserve, and other areas have been established as game sanctuaries. A portion of the lands important to native parrots (Blue Mountains, John Crow Mountains, Portland Ridge, Cockpit Country, and major swamps) have been designated potential national parks under the National Physical Plan for Jamaica (1971-1980). However, areas identified on maps as national parks have not yet been accurately delineated on the lands themselves or given effective protection.

The Jamaican Natural Resources Conservation Department is responsible for wildlife preservation and parrots have full protection under section six of the Jamaican Wildlife Protection Act (1974), administered by the Ministry of Agriculture, Natural Resources Conservation Division. In 1986, Amazona collaria and $A$. agilis were listed as "threatened" by the Jamaican government. Also, stringent gun control has been instituted by the Jamaican government. All of these policies have resulted in a general awareness of the legal status of parrots among Jamaicans. A decrease in meat hunting, including for parrots, has been a byproduct of the control. However, parrots are still harvested for exportation for the pet trade and a stricter enforcement policy on taking parrot chicks is needed (Downer and Sutton 1990). In 1979, an estimated 530 Jamaican parrots were imported into the United States from Jamaica (TRAFFIC-USA 1980). In 1983, 20 illegally exported parrots were returned to Jamaica from England. Amazona collaria is more affected by commercial exploitation than A. agilis. The Jamaican government has not ratified CITES. 
Of current concern is the habitat destruction wrought by Hurricane Gilbert, which swept through some of the most important parrot areas (Varty 1991). Although populations of Black-billed Parrots and Yellow-billed Parrots appear to have survived the storm well, the long-term survival of these species is in doubt because of hurricane-related reductions in food supplies and nest-site availability, combined with continuing habitat destruction and disturbance by humans (Varty 1991). Hardest hit by the storm were the high montane regions, where damage was greatest to trees along exposed ridges and the crests of hills (Varty 1991, J. Wunderle, pers. comm.).

Although a captive breeding programme for the Amazona parrots has been established in Jamaica, some of the five aviaries were damaged by Hurricane Gilbert. Fortunately, Amazona collaria is being bred in good numbers in England.

Cruz and Fairbairn (1980) presented recommendations that are applicable to all Jamaican species of psittacines: (1) preserve and actively protect habitat, including additional areas for parrot sanctuaries (e.g., lands in the Cockpit Country, Mount Diablo, and Corn Puss Gap); (2) institute education programmes; (3) prevent importation of exotics; (4) regulate the exportation of parrots; and (5) enact protective legislation that will ensure the future of the species (Cruz and Gruber 1981).

\section{Yellow-billed Parrot Amazona collaria}

Distribution and habitat Amazona collaria populations are concentrated in two regions: (1) Cockpit Country from sea level (Trelawny and St Ann) to about 1,200 m elevation, and (2) the John Crow Mountains (Bond 1956, Lack 1976, Cruz and Gruber 1981; Figure 10).

In addition, the Yellow-billed Parrot inhabits the eastern Blue Mountains

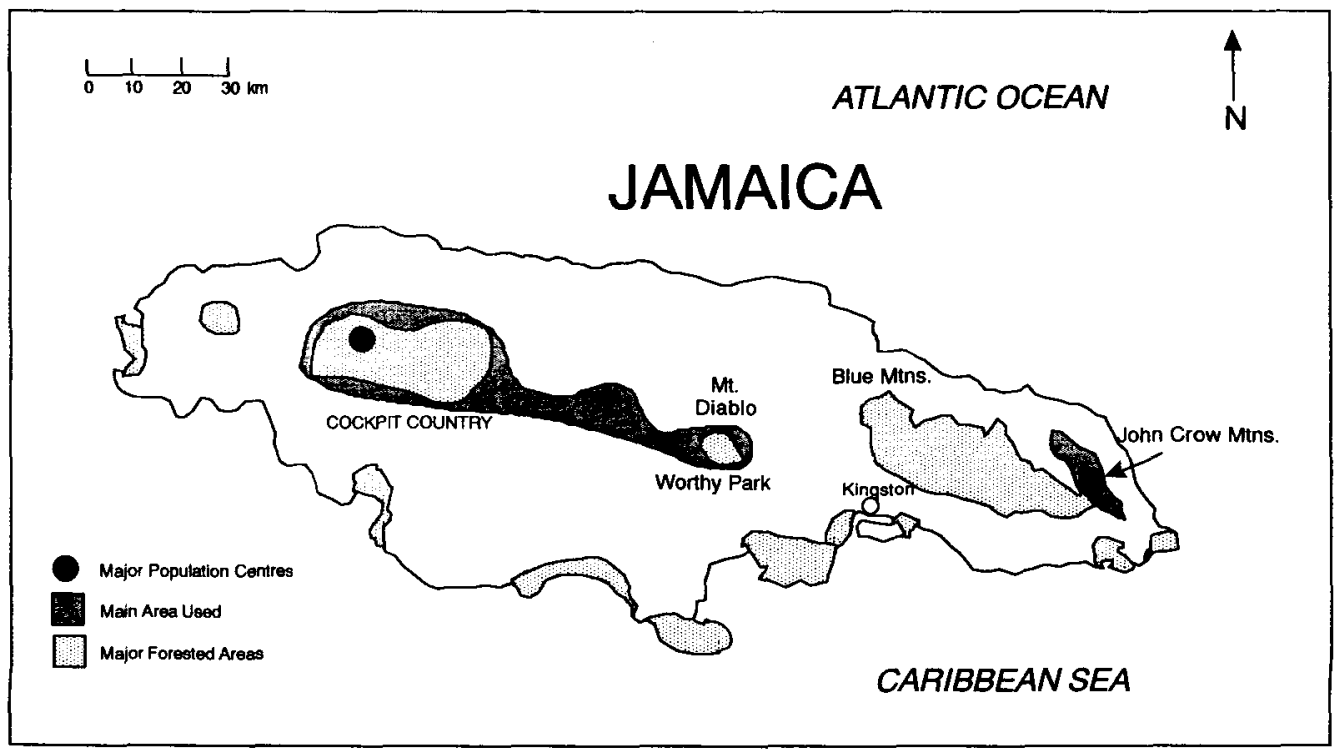

Figure 10. Distribution of the Yellow-billed Parrot Amazona collaria, showing main area of distribution and major population centres. 
(rare), Mt Diablo, and occasionally visits other parts of this mountain range and some wooded cultivation bordering forests (Lack 1976, Downer and Sutton 1990). It is an occasional visitor as well to wooded cultivation in higher elevations of the southern lowlands (Kingston-Spanish Town area: Lack 1976). The parrot uses forested and semi-forested lands in the mid-level wet limestone regions, and lower montane areas of Mt Diablo and the John Crow Mountains.

Status The Yellow-billed Parrot is fairly common in suitable habitat (Lack 1976, Cruz and Gruber 1981).

Population trend Although Amazona collaria is decreasing in range and numbers, the species appears to be in no immediate danger of extinction (Cruz and Gruber 1981, Fairbairn 1981, Varty 1991).

\section{Black-billed Parrot Amazona agilis}

Distribution and habitat The Black-billed Parrot is found primarily in the midlevel wet limestone forests. Although formerly noted as common in Portland Parish (Scott 1891-1893), by the mid-1970s A. agilis had become rare in the eastern part of the island (Port Antonio in Portland Parish, and Corn Puss Gap in the John Crow Mountains: Cruz and Gruber 1981; Figure 11). Amazona agilis was formerly as abundant as A. collaria in the Cockpit Country and Mt Diablo (Lack 1976), but agilis is now decidedly less common than collaria in parts of this region (Chandler Robbins pers. comm. 1989, Downer and Sutton 1990). Amazona agilis is also found in the interior hills of Trelawny and St Ann.

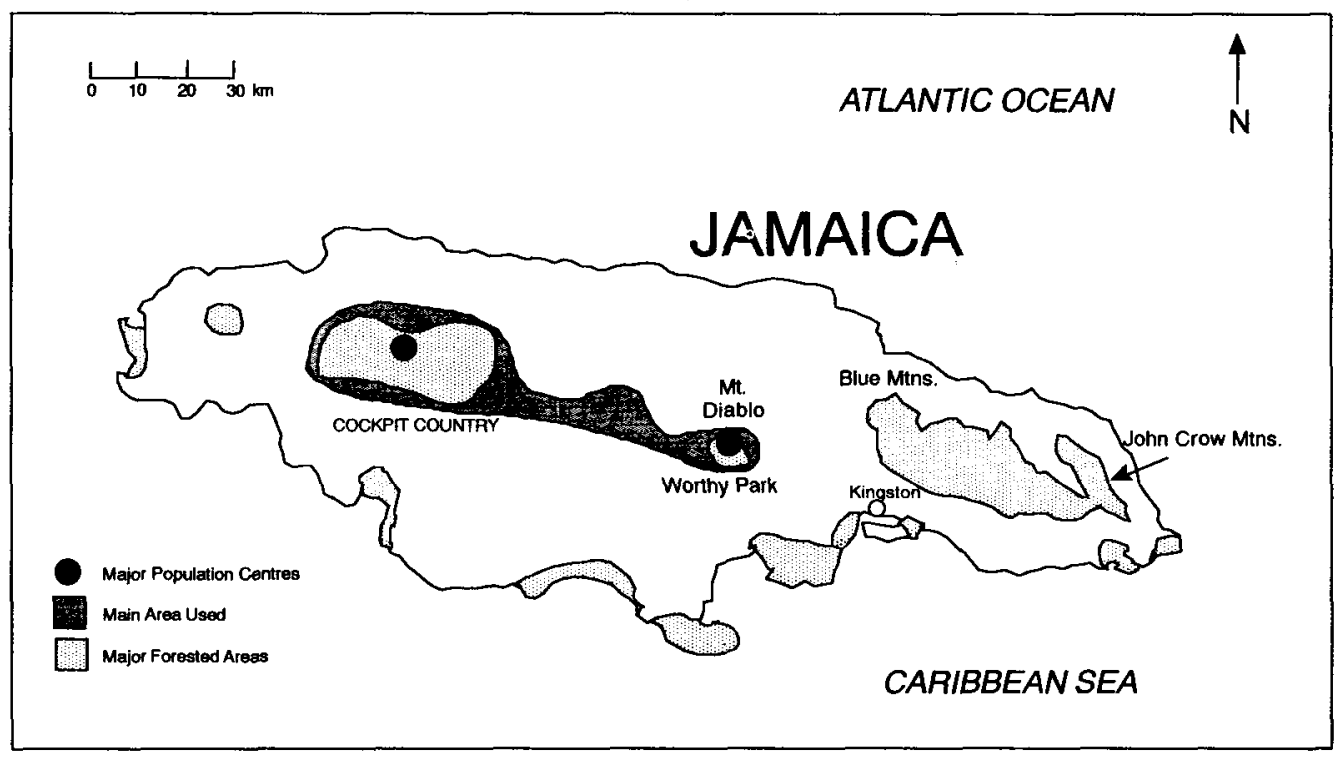

Figure 11. Distribution of the Black-billed Parrot Amazona agilis, showing main area of occurrence and major population centres. 
Status Amazona agilis is a fairly common resident in appropriate habitat, but appears to have undergone a reduction in numbers in the eastern part of its range (Cruz and Gruber 1981), and indeed Chandler Robbins (pers. comm. 1989) believes agilis populations have substantially declined throughout. However, the Black-billed Parrot is apparently not in immediate danger of extinction (see Varty 1991).

Population trend The Black-billed Parrot is undergoing a slow decline in numbers and becoming restricted in range (Fairbairn 1981).

\section{Olive-throated Parakeet Aratinga nana}

Distribution and habitat The Olive-throated Parakeet was once found in nearly all parts of the island, from lowlands to moderate elevations, but was rare in, or absent from, the higher mountains (Bond 1956). More recently, it has been reported as commonest in midland wet limestone forest, wooded cultivation at mid-levels, scrub in humid and semi-arid areas, gardens, and in the northern lowlands (Lack 1976, Downer and Sutton 1990). In the southern lowlands, it occurs in wooded cultivation and the less arid parts of the secondary woodlands (Lack 1976). The parakeet intermittently visits the arid natural forests of the Hellshires and Portland Ridge, but is generally absent from ruinate woodland. It is occasionally seen in wooded cultivation in the Blue Mountains, but is absent from the wet John Crow Mountains.

Status Aratinga nana, formerly known as the Jamaican Parakeet, has recently been combined with Aratinga astec (Aztec Parakeet) under $A$. nana, to include populations of Jamaica and Middle America from southern Tamaulipas and Veracruz south to western Panama (American Ornithologists' Union 1983). The Jamaican population is considered a distinct race $(A . n$. nana). Although the parakeet's status is not adequately known in Jamaica, it is apparently becoming restricted in range through loss of habitat. By the late nineteenth century, the Olive-throated Parakeet was already local in distribution, but was still common in those areas (Scott 1892). Most recent reports have also described the parakeet as locally common (Bond 1956, Cruz 1972), although Downer and Sutton (1990) believed the species was common and widespread.

Population trend Unknown, but likely decreasing.

Threats The Olive-throated Parakeet is a serious enemy of corn planters (Danforth 1928) and has been much persecuted for its depredations (Downer and Sutton 1990)

\section{Hispaniola}

The Dominican Republic and Haiti, which comprise Hispaniola, have forested habitats undergoing accelerating degradation. The prospect for wildlife conservation is poorer in Haiti than in any other country in the West Indies because of rampant habitat destruction caused by an impoverished and growing human 
population. By the 1950s, forests (mixtures of degraded hardwoods and a few pines) covered a mere $7 \%$ of the land area, which was originally completely forested (Burns 1954). Habitat loss has continued, as demonstrated by recent transects in the important wildlife area of the Massif de la Hotte. These transects revealed only $2.4 \%$ of the region consisted of virgin forest (Cohen 1984). If current trends go unchecked, the most valuable forested lands in north-western Haiti, large zones of southern Haiti, and Pic Macaya (Massif de la Hotte) will be totally deforested before the end of the twentieth century (Cohen 1984). With more than 200 people $/ \mathrm{km}^{2}$ (1982), a mean per capita income of US\$150/year for rural residents and the present unstable government, the outlook for conservation in Haiti seems near hopeless. Nevertheless, an effort must be made to achieve an immediate improvement in conservation in Haiti.

Woods (1987) presented recommendations vital to the conservation of the parrot and parakeet in Haiti. Perhaps the most important of these recommendations was that mature broadleaf forest habitat, particularly in regions of the national parks, must be preserved and provided with greater protection. Woods believed a vigorous conservation programme is essential if these parrot species are to be saved from extinction in Haiti. That programme must include development and enforcement of legislation to prevent exploitation for the pet trade.

The rampant destruction of old-age forests in Haiti must be stopped if parrots and other wildlife species are to survive beyond the next decade. At present, only two recently established and poorly managed national parks exist: Parc National Macaya and Parc National La Visite.

In contrast, the Dominican Republic has nine national parks and five scientific reserves, managed, to a somewhat greater degree, by the government agency Dirección Nacionales de Parques. The Dominican Republic ratified CITES in 1987, whereas the Haitian government has not signed the treaty.

\section{Hispaniolan Parrot Amazona ventralis}

Distribution and habitat The parrot was formerly common and widespread throughout Hispaniola and its satellites, inhabiting arid lowland, palm savannas and, more commonly, high mountain forests (Wetmore and Swales 1931, Bond 1956, Stockton de Dod 1978, pers. obs.). It is now primarily restricted to the remoter forested areas (Figure 12).

In the Dominican Republic, the parrot is still found in moderate numbers in parts of the Sierra de Baoruco, Sierra Neiba, and Cordillera Central, whereas the Haitian populations of the species are much smaller and more restricted in range. Woods (1987) reported parrots almost absent from the Parc National La Visite (Massif de la Selle) and he discovered none on the upper slopes of either Pic Formon or Pic Macaya in the important Parc National Macaya (Massif de la Hotte) in 1984-1985. However, he recorded them as common in the karst of the Plain of Formon.

Status The Hispaniolan Parrot is locally common in the Dominican Republic, but must be considered uncommon or rare over much of its former range (Stockton de Dod 1978, Woods 1987, pers. obs.). Hartshorn et al. (1981) list the parrot as in danger of extinction in the Dominican Republic. Woods (1987), using U.S. 


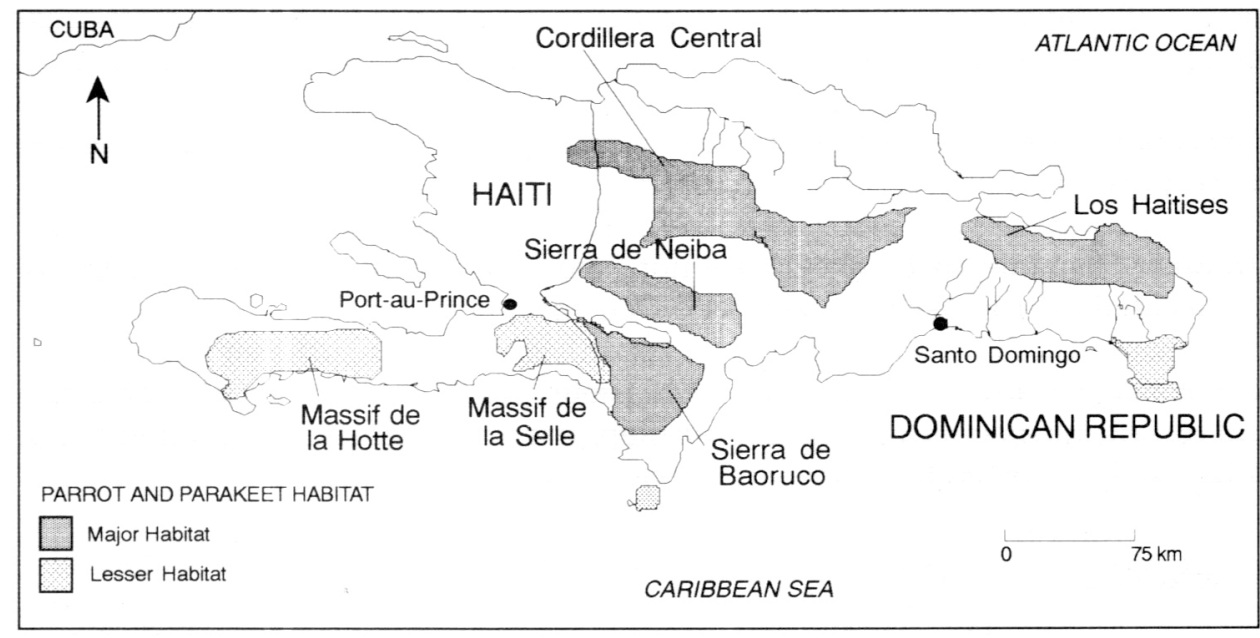

Figure 12. Areas important to the Hispaniolan Parrot Amazona ventralis, showing major and lesser habitats.

legal terminology, described the parrot as endangered throughout Haiti, except in the Plains of Formon and the surrounding mid-elevation areas of southern Haiti. In these locales, he reported the bird uncommon, but threatened, rather than endangered.

Population trend The Hispaniolan Parrot is rapidly decreasing in distribution and numbers throughout its range (Stockton de Dod 1978, 1981, Woods 1987, pers. obs.). Stockton de Dod (1978) reported that its numbers have declined dramatically in the 1970 and that the parrot was on the way to extinction in the Dominican Republic.

Threats Hispaniolan Parrots are regularly hunted for food, shot as crop pests, and taken for pets (pers. obs.). Still, habitat destruction is the most important factor in the parrot's past and present decline.

Conservation efforts The parrot is protected by law (DR-1975-Regulation 601) against chick harvesting and hunting in the Dominican Republic.

Hispaniolan Parakeet Aratinga chloroptera

Distribution and habitat The parakeet was formerly common throughout Hispaniola and on several of the offshore islands with suitable habitat, i.e. all natural habitats, but especially pine forests and high mountain forests of the interior (Bond 1928, Wetmore and Swales 1931, Bond 1956, Stockton de Dod 1978 , pers. obs.). In the Dominican Republic, it is now mostly confined to remoter areas, particularly the Sierra de Baoruco, Sierra Neiba, Cordillera Central, Los Haitises, and lowlands around Lago Enriquillo, but it also occurs sparsely in hills around agricultural areas (pers. obs.). Parakeet populations are smaller and more restricted in range in Haiti, where they perhaps reach highest densities in the Massif de la Selle and Massif de la Hotte. 
Status Endangered (Hartshorn et al. 1981) in the Dominican Republic. Stockton de Dod (1981) also considered the parakeet declining toward extinction.

Population trend The parakeet is rapidly declining in numbers (Stockton de Dod 1981, pers. obs.).

Threats Hispaniolan Parakeets are not favoured as captives, but are severely persecuted as crop pests (Stockton de Dod 1978, pers. obs.).

Conservation measures The parakeet is protected by law against shooting and harvesting for pets in the Dominican Republic, although this legislation is not adequately enforced to ensure the species's continued survival.

\section{Puerto Rico}

Perhaps no island has undergone as much dramatic environmental degradation as Puerto Rico, where only about one per cent of the original vegetation remains. The fact that the Puerto Rican Parakeet Aratinga (chloroptera) maugei became extinct and the Puerto Rican Parrot has precipitously declined is not remarkable in view of the near-complete habitat loss. What is remarkable is that any Puerto Rican parrots survived.

\section{Puerto Rican Parrot Amazona vittata}

Distribution and habitat The Puerto Rican Parrot formerly occurred throughout all forested regions of Puerto Rico and its offshore islands of Mona, Vieques, and Culebra (Wiley 1981, Snyder et al. 1987). It is now restricted to portions of the wet montane Luquillo Forest of eastern Puerto Rico. A subspecies inhabiting Culebra Island became extinct at the end of the nineteenth century (Wetmore 1917).

Status With one of the smallest populations of birds for which accurate figures are known, the Puerto Rican Parrot is considered critically endangered (King 1978-1979). An estimated minimum of 100,000 birds existed when Columbus arrived in Puerto Rico in 1493. By 1975, the wild population had reached a low point of 13 individuals (Wiley 1981, Snyder et al. 1987). By the mid-1980s, the population decline had ceased and in August 1989 the count of wild parrots stood at a minimum of 47 birds (Marcia Wilson pers. comm.). However, in September 1989, the Luquillo Forest suffered a direct hit by Hurricane Hugo. Subsequent counts of parrots revealed that no more than 23 birds survived the storm. Nevertheless, the wild population bred the following season and a minimum of 22-23 parrots were counted in October 1990. Breeding efforts of the wild population in 1991 have been especially encouraging; a 24-year record high of six pairs have established nest sites.

A captive programme within the Luquillo Forest, begun in 1970, now consists of 56 individuals ( 24 males, 23 females, nine unsexed: T. Sorenson pers. comm. 1991) of good genetic diversity. The captive parrots have been producing off- 
spring since 1979. Several chicks have been fostered into wild nests, and three other chicks were released as fledglings.

Population trend The wild population is slowly growing in numbers. However, it is still restricted to only one small forest (of around 11,000 ha), and remains at risk of extinction from disease and hurricanes. The captive population is increasing.

Threats Perhaps the most serious threats facing the remnant Puerto Rican Parrot population are disease, habitat loss through a direct hit by a hurricane, and genetic problems resulting from the depressed diversity of a population consisting of no more than five breeding pairs per year for two decades.

Conservation efforts The Puerto Rican Parrot is protected by Puerto Rico Commonwealth and United States federal laws, and is listed in Appendix I of CITES (1975). Puerto Rico, through its Commonwealth relationship with the United States, is a signatory of CITES. The parrot's habitat, now entirely confined within the boundaries of the Caribbean National Forest, is protected from most dangers. Nevertheless, a recent threat (1986) to this reserve came from the U.S. Forest Service's plans to harvest timber. Fortunately, those plans were thwarted by negative public response. The latest threat is the programme to reconstruct a major highway through parrot habitat in the forest.

Through seed money from the World Wildlife Fund and the interest of Frank Wadsworth (U.S. Department of Agriculture - Forest Service) and Ray Erickson (U.S. Fish and Wildlife Service), an intensive programme of research and conservation was begun in 1968. The programme has continued through to the present, with the primary involvement of the U.S. Forest Service, Commonwealth of Puerto Rico Department of Natural Resources, and U.S. Fish and Wildlife Service.

The goal of the conservation programme is to develop a strategy for the parrot's recovery, based on sound biological data. The programme consists of: (1) predator and competitor control - especially Pearly-eyed Thrashers Margarops fuscatus, honeybees Apis mellifera, and black rats Rattus rattus; (2) management of nest cavities - improvement of natural cavities and provisioning of additional artificial nest sites; (3) close guarding of active nests to maximize chick survival; (4) captive breeding - to serve as insurance against extirpation of the wild population through a natural disaster, as a source of chicks to add to the wild population, and as a "gene bank" to preserve genetic diversity of the population. A second captive population, vital to the recovery of the species, is to be established in the Commonwealth of Puerto Rico's Río Abajo Forest in northwestern Puerto Rico. An aviary facility was recently completed there and captive-produced parrots will eventually be released in this and other forests remote from the Luquillo population.

Recommendations I consider the following essential to the recovery of the Puerto Rican Parrot. (1) A strong commitment to long-term research should continue. (2) The conservation programme must continue to emphasize both the study of 
the wild population and the captive production of chicks. (3) The wild population should not be compromised by excessive harvesting of chicks for the captive propagation programme. Chicks should be taken only when a clear genetic need exists within the captive flock or in individual rescue situations. (4) Captiveproduced chicks should continue to bolster the wild population. (5) A major research effort should be made to determine how to improve recruitment of birds into the breeding cohort. (6) Close guarding of active wild nests should persist.

\section{Conclusions}

All native psittacines in the Greater Antilles, Bahama Islands and Cayman Islands have experienced substantial population declines or extinctions in the twentieth century (Table 1). Because of the tenuous success of the conservation programme for the Puerto Rican Parrot, there is guarded optimism that the species will recover. However, Puerto Rico, with its political ties to the United States, is unique in that its economic base is considerably better than can be expected for other countries in the region. An expensive programme like that for the Puerto Rican Parrot is not feasible for species on other islands. Thus, it is imperative that conservation efforts begin early enough to avoid the desperate measures needed to recover severely reduced populations (Soule 1987). In developing conservation programmes for the region's parrots, the following points need to be considered:

Table 1. Status of species of Amazona and Aratinga in the Greater Antilles, Bahama Islands, and Cayman Islands. Only native species and species introduced more than 75 years ago are included

\begin{tabular}{|c|c|c|}
\hline Island & Species & Status \\
\hline \multirow[t]{3}{*}{ Cuba } & Aratinga euops & $\begin{array}{l}\text { Declining, extirpated from Isla de la } \\
\text { Juventud (Isle of Pines) }\end{array}$ \\
\hline & Amazona leucocephala leucocephala & Declining \\
\hline & Amazona l. palmarum & Declining \\
\hline Grand Cayman & Amazona l. caymanensis & Small population, stable? \\
\hline Cayman Brac & Amazona l. hesterna & Tiny population, endangered \\
\hline Little Cayman & Amazona l. hesterna & Extirpated \\
\hline Bahama Islands & Amazona l. bahamensis & $\begin{array}{l}\text { Common on Inagua, threatened on Abaco, } \\
\text { extirpated on other islands }\end{array}$ \\
\hline \multirow[t]{4}{*}{ Jamaica } & Aratinga nana & Declining, but still locally common \\
\hline & Amazona collaria & Small population, declining \\
\hline & Amazona agilis & Small population, declining \\
\hline & Forpus passerinus & Introduced, locally common \\
\hline \multirow[t]{2}{*}{ Hispaniola } & Aratinga chloroptera & Declining \\
\hline & Amazona ventralis & $\begin{array}{l}\text { Widespread and locally common, but } \\
\text { declining rapidly }\end{array}$ \\
\hline \multirow[t]{2}{*}{ Puerto Rico } & Aratinga maugei & Extinct \\
\hline & Amazona vittata vittata & $\begin{array}{l}\text { Tiny population, endangered, but with an } \\
\text { aggressive conservation programme }\end{array}$ \\
\hline Culebra Island & Amazona vittata gracilipes & Extinct \\
\hline Virgin Islands & Aratinga pertinax & $\begin{array}{l}\text { Common, believed introduced from } \\
\text { Curaçao }\end{array}$ \\
\hline
\end{tabular}


1. A vigorous programme of field research is essential to determine the ecological requirements of each parrot species. Long-term, multigenerational projects are vital for providing suitable data for developing realistic conservation programmes for any species.

2. Conservation efforts should evaluate habitat quality, including availability of suitable nest cavities and feeding resources, and the nature of interactions of parrots with competitors and predators. Feral predators and competitors should be vigorously controlled.

3. The impact of poaching and habitat encroachment for natural resources and agriculture should be determined.

4. Protected feeding, nesting, and shelter habitat within reserves of adequate size should be established.

5. Legislation suitable for protection of parrots, including regulations to control the harvest of parrots, should be developed and enforced.

6. Approaches culturally, politically, and economically sensitive to human needs should be developed and conservation-oriented education programmes must be formulated.

7. Better data are needed on numbers, distribution, habitat status, and population trends for all populations. Surveys of representative wild populations at reasonable intervals are critical for the development of a conservation strategy for each species and for parrots region-wide.

8. Careful consideration should be given to the value of captive propagation to a species's recovery. Captive-breeding programmes can be very costly longterm commitments and, too often, are conducted at the expense of muchneeded research on the wild populations while those populations continue to decline (Snyder and Derrickson 1991). The potential of reintroduction from captive-bred stock to rebuild the natural world should not be overstated (Wiley et al. 1991b).

9. Captive-breeding programmes, when determined to be essential and feasible for a species's recovery, should begin before it becomes necessary to remove stock from the wild at the expense of the wild population's health.

10. Captive flocks should consist of a wide diversity of individual lines (founder stocks) from the wild.

11. Countries should be encouraged to become signatories to CITES.

12. A system of secure forest reserves of a size capable of supporting viable, self-sustaining populations of parrots should be established on each island.

13. Human population growth and associated habitat conversion threaten parrots on all islands where these birds survive. Human populations must be at least stabilized if parrots are to have any hope of continuing to exist in the region.

\section{Acknowledgements}

I thank Chandler Robbins, Cameron Kepler, Marcia Wilson and Nigel Collar for offering comments that improved the manuscript. 


\section{References}

Allen, G. M. (1905). Summer birds in the Bahamas. Auk 22: 113-133.

American Ornithologists' Union (1983) Check-list of North American birds. Sixth edition. American Ornithologists' Union.

Asprey, G. F. and Robbins, R. G. (1953) The vegetation of Jamaica. Ecol. Monogr. 23: 359-412.

Attrill, R. (1981) The status and conservation of the Bahama Amazon (Amazona leucocephala bahamensis). Pp. 81-87 in R. F. Pasquier, ed. Conservation of New World parrots. Washington, D.C.: Smithsonian Institution Press for the International Council for Bird Preservation (Techn. Publ. 1).

Bangs, O. (1916) A collection of birds from the Cayman Islands. Bull. Mus. Comp. Zool. 60: 303-320.

Bangs, O. and Zappey, W. R. (1905) Birds of the Isle of Pines. Amer. Nat. 39: 179-215.

Barbour, T. (1943) Cuban ornithology. Mem. Nuttall Orn. Club no. 9.

Berovides Alvarez, V. (1986) Nidificacíon de la cotorra de Cuba (Amazona leucocephala) en la Isla de la Juventud. Ciencias Biologicas 15: 133-135.

Bond, J. (1928) The distribution and habits of the birds of the Republic of Haiti. Proc. Acad. Nat. Sci. Philadelphia 80: 483-521.

Bond, J. (1956) Check-list of birds of the West Indies. Fourth edition. Philadelphia: Academy of Natural Sciences of Philadelphia.

Bradley, P. E. (1986) A report of a census of Amazona leucocephala caymanensis, Grand Cayman and Amazona leucocephala hesterna, Cayman Brac. George Town, Grand Cayman: Cayman Islands Government Tech. Publ. no. 1.

Buden, D. W. (1979) Ornithogeography of the southern Bahamas. Ph.D. dissertation, Louisiana State University and Agricultural Mechanical College.

Burns, L. V. (1954) Report to the government of Haiti on forestry policy and its implementation. Rome: United Nations FAO (Rept. 346).

Cohen, W. B. (1984) Environmental degradation in Haiti: an analysis of aerial photography. Port-au-Prince, Haiti: USAID/Haiti.

Cruz, A. (1972) Birds of the Lluides Vale (Worthy Park) Region, Jamaica. Quart. J. Florida Acad. Sci. 35: 72-80.

Cruz, A. and Fairbairn, P. (1980) Conservation of natural resources in the Caribbean: the avifauna of Jamaica. Trans. N.A. Wildl. Natural Resources 45: 438-444.

Cruz, A. and Gruber, S. (1981) The distribution, ecology, and breeding biology of Jamaican amazon parrots. Pp. 103-131 in R. F. Pasquier, ed. Conservation of New World parrots. Washington, D.C.: Smithsonian Institution Press for the International Council for Bird Preservation (Techn. Publ. 1).

Danforth, S. T. (1928) Birds observed in Jamaica during the summer of 1926. Auk 45: 480-491.

Davis, D. E. (1941) Notes on Cuban birds. Wilson Bull. 53: 37-40.

Downer, A. and Sutton, R. (1990) Birds of Jamaica. New York: Cambridge University Press.

Fairbairn, P. (1981) Parrot conservation in Jamaica. Pp. 95-101 in R. F. Pasquier, ed. Conservation of New World parrots. Washington, D.C.: Smithsonian Institution Press for the International Council for Bird Preservation (Techn. Publ. 1).

Forshaw, J. M. (1978) Parrots of the world. Second edition. Melbourne, Australia: Lansdowne Editions.

García Montaña, F. (1980) Las aves de Cuba, 1. Especies endémicas. La Habana, Cuba: Editorial Gente Nueva.

García Montaña, F. (1987) Las aves de Cuba, 2. Subespecies endémicas. La Habana, Cuba: Editorial Gente Nueva.

Garrido, O. H. and García Montaña, F. (1975) Catálogo de las aves de Cuba. La Habana: Academia de Ciencias de Cuba. 
Gnam, R. (1988) Preliminary results on the breeding biology of the Bahama Amazon. Parrotletter 1: 23-26.

Gnam, R. (1990) Conservation of the Bahama Parrot. Amer. Birds 44: 32-36.

Gnam, R. and Burchsted, A. (1991) Population estimates for the Bahama Parrot on Abaco Island, Bahamas. J. Field Orn. 62: 139-146.

Gnam, R. and Rockwell, R. F. (in press) Reproductive potential and output of the Bahama Parrot (Amazona leucocephala bahamensis). Ibis.

Gundlach, J. (1893) Ornithología cubana, o catálogo descriptivo de todas las especies de aves tanto indigenas como de paso anual o accidental observadas en 53 años. Habana.

Hartshorn, G., et al. (1981) The Dominican Republic; a country environmental profile. AID contract no. AID/SOD/PDC-C-0247. JRB Assoc., Virginia.

Instituto Cubano de Geodesia y Cartografia (1978) Atlas de Cuba. La Habana.

Johnston, D. W. (1975) Ecological analysis of the Cayman Island avifauna. Bull. Florida Acad. Sci. 19: 235-300.

King, W. B. (1978-1979) Red Data Book, 2: Aves. Second edition. Gland, Switzerland: International Union for Conservation of Nature and Natural Resources.

Lack, D. (1976) Island biology illustrated by the land birds of Jamaica. Oxford: Blackwell (Studies in Ecology 3).

Lehman, P. (1989) The changing seasons - Autumn 1988. Amer. Birds 43: 50-54.

Moore, A. G. (1985) Winter status of birds on Grand Cayman Island. Bull. Brit. Orn. Club 105: 8-17.

Morison, S. E., ed. (1963) Journals and other documents on the life and voyages of Christopher Columbus. New York: Limited Editions Club.

Nicoll, M. J. (1904) On a collection of birds made during the cruise of the Valhalla, R.Y.S., in the West Indies (1903-4). Ibis (8)4: 555-591.

Noegel, R. (1974) Breeding the Cayman Brac Amazon Amazona leucocephala hesterna. Avicult. Mag. 80: 17-28.

Noegel, R. (1976) The Cayman Brac Amazon. Avicult. Mag. 82: 202-208.

Noegel, R. (1977) Captive breeding of Amazona leucocephala. Avicult. Mag. 83: 126-130.

Noegel, R. (1981) Amazona leucocephala: status in the wild and potential for captive breeding. Pp. $73-79$ in R. F. Pasquier, ed. Conservation of New World parrots. Washington, D.C.: Smithsonian Institution Press for the International Council for Bird Preservation (Techn. Publ. 1).

Olson, S. L., James, H. F. and Meister, C. A. (1981) Winter field notes and specimen weights of Cayman Island birds. Bull. Brit. Orn. Club 101: 339-346.

Philibosian, R. and Yntema, J. A. (1977) Annotated checklist of the birds, mammals, reptiles, and amphibians of the Virgin Islands and Puerto Rico. Frederiksted, St Croix, U.S. Virgin Islands: Information Services.

de las Pozas, G. and González, H. (1984) Disminución de los sítios de nidificación de cotorra y catey (Aves: Psittacidae) por la tala de palmas en Ciénaga de Zapata, Cuba. Misc. Zool. Inst. Zool. Acad. Cienc. Cuba 18: 4-11.

Raffaele, H. A. (1983) A guide to the birds of Puerto Rico and the Virgin Islands. San Juan, Puerto Rico: Fondo Educativo Interamericano.

Rodríguez-Vidal, J. A. (1959) Puerto Rican Parrot study. Monogr. Dep. Agric. Comm. Puerto Rico No. 1.

Rodríguez, D. and Acosta, M. (1986) Observaciones etológicas sobre la cotorra (Amazona leucocephala leucocephala) en cautiverio. La Habana, Cuba: Rep. Invest. Acad. Ciencias Cuba, Inst. Zool., No. 29.

Scott, W. E. D. (1891-1893) Observations on the birds of Jamaica, West Indies. Auk 8: 249256, 353-365; 9: 9-15, 120-129, 273-277, 369-375; 10: 177-181, 339-342.

Snyder, N. F. R. and Derrickson, S. R. (1991) The role of captive breeding in conservation of parrots. In S. Beissinger and N. F. R. Snyder, eds. Crisis in New World parrot conservation. Washington, D.C.: Smithsonian Press. 
Snyder, N. F. R., King, W. B. and Kepler, C. B. (1982) Biology and conservation of the Bahama Parrot. Living Bird 19: 91-114.

Snyder, N. F. R., Wiley, J. W. and Kepler, C. B. (1987) The parrots of Luquillo: the natural history and conservation of the Puerto Rican Parrot. Los Angeles, California: Western Foundation of Vertebrate Zoology.

Soulé, M. (1987) Viable populations for conservation. Cambridge: Cambridge University Press.

Stockton de Dod, A. (1978) Aves de la República Dominicana. Santo Domingo: Museo Nacional de Historia Natural.

Stockton de Dod, A. (1981) Guia de campo para las aves de la República Dominicana. Santo Domingo: Museo Nacional de Historia Natural.

Symes, G. (1971) The Jamaican forests. Jamaican J. 5: 32-36.

Todd, W. E. C. (1916) The birds of the Isle of Pines. Ann. Carnegie Mus. 10: 146-296.

TRAFFIC-USA (1980) Neotropical psittacines in trade. Washington, D.C.: TRAFFIC (U.S.A.).

U.S. Bureau of Sport Fisheries and Wildlife (1970) List of endangered foreign fish and wildlife. U.S. Federal Regulations 35(233): 18319-18322.

Varty, N. (1991) The status and conservation of Jamaica's threatened and endemic forest avifauna and their habitats following Hurricane Gilbert. Bird Conserv. Internatn. 2: 135-151.

Vincent, J. (1966-1971) Red Data Book, 2: Aves. Morges, Switzerland: International Union for Conservation of Nature and Natural Resources.

Wetmore, A. (1917) The birds of Culebra Island, Porto Rico. Auk 34: 51-62.

Wetmore, A. and Swales, B. H. (1931) The birds of Haiti and the Dominican Republic. Bull. U.S. Natn. Mus. 155: 1-483.

Wiley, J. W. (1981) The Puerto Rican Parrot (Amazona vittata): its decline and the program for its conservation. Pp. 133-159 in R. F. Pasquier, ed. Conservation of New World parrots. Washington, D.C.: Smithsonian Institution Press for the International Council for Bird Preservation (Techn. Publ. 1).

Wiley, J. W. (1985) The Puerto Rican Parrot and competition for its nest sites. Pp. 213-223 in P. J. Moors, ed. Conservation of island birds. Cambridge, U.K.: International Council for Bird Preservation (Techn. Publ. 3).

Wiley, J. W., Ground McCoy, D., Cross, S., Scharr, P., Burton, F., Ebanks-Petrie, G., Marsden, M., Butler, P. and Prescott, K. (1991a) Report on surveys of the Cayman Brac Parrot (Amazona leucocephala hesterna) on Cayman Brac, February 1991. George Town, Grand Cayman: National Trust for the Cayman Islands.

Wiley, J. W., Snyder, N. F. R. and Gnam, R. (1991b) Reintroduction as a conservation strategy for parrots. In S. Beissinger and N. F. R. Snyder, eds. Crisis in New World parrot conservation. Washington, D.C.: Smithsonian Press.

Wiley, J. W. (in press a) Natural range expansion and local extinction of an exotic psittacine - an unsuccessful colonization attempt. Neotropical Orn.

Wiley, J. W. (in press b) Effects of hurricanes on island wildlife. J. Soc. Carib. Orn. 1.

Woods, C. A. (1987) The threatened and endangered birds of Haiti: lost horizons and new hopes. Pp. 385-429 in A. C. Risser, ed. Proc. Jean Delacour Symposium on Breeding Birds in Captivity. Los Angeles, California: International Foundation for the Conservation of Birds.

\section{JAMES W. WILEY}

Patuxent Wildlife Research Center, U.S. Fish and Wildlife Service, Laurel, Maryland 20708, U.S.A. Mailing address: Southwest Research Group, U.S. Fish and Wildlife Service, 2140 Eastman Ave., Suite 100, Ventura, California 93003, U.S.A. 